\title{
A Review of Self-esteem of the Hearing Impaired Football Players
}

\author{
Mahmut Açak ${ }^{1}$, Oktay Kaya ${ }^{2, *}$ \\ ${ }^{1}$ School of Physical Education and Sports, Inonu University, Turkey \\ ${ }^{2}$ School of Physical Education and Sports, Kafkas University, Turkey
}

Copyright $\mathrm{O} 2016$ by authors, all rights reserved. Authors agree that this article remains permanently open access under the terms of the Creative Commons Attribution License 4.0 International License

\begin{abstract}
The current study aimed at reviewing the level of self-esteem of the hearing impaired football players. The sample of the study was composed of 95 football players who played in the $1^{\text {st }}$ hearing impaired football league. To gather the study-data; a Personal Information Form and Self-esteem Scale were used. The data obtained were analyzed through statistical software. It was seen that self-esteem of the participant hearing impaired football players were moderate. It was found that no statistically significant differences existed among the mean self-esteem scores of the hearing impaired football players in terms of age, sportive age, educational status and living-place variables.
\end{abstract}

Keywords Hearing Impairment, Football, Self-esteem

\section{Introduction}

Individuals try to undertake a social role in society from the time of birth. This process of undertaking social roles is an ongoing one. The value that an individual attributes to them self during this process is considered to be directly related to sense of self. Every individual fulfills certain roles in their life. The concept of self refers to how a person perceives them self with regard to these roles. Self-esteem involves a person's feelings and thoughts about them self. Self-esteem focuses on the human need for self-evaluation or a positive self-evaluation. This does not necessarily mean feeling oneself to be perfect, adequate and proficient; it means self-acceptance, identity formation and the acceptance of others [1].

'Self-esteem' is an important and commonly used term used in the western world, particularly in the USA. In France, "narcissism" is used instead of the term [2]. Self-esteem is positive or negative attitudes towards individuals themselves or the degree of self-perception that indicates that individuals feel competent, safe and important. It is known that poor self-esteem causes a rather stiff life philosophy, introversion, passive behaviors, psychosomatic disorders and aggressive behaviors [3]. Upon the self-conception of the children; the effect of the family, which is the first social environment in which the children interact, is very important. That families' socio-economic and cultural structures and their attitudes towards the children affect their personality development is a theme with which nearly all the theoreticians have agreed [4]. Those children loved by their families and social circles are above the average in terms of intelligence, school success and health; trust themselves more and become sensitive to others' opinions and interests [5].

For Chrzanowski, self-esteem, in the widest sense, is positive image of oneself based on a fair appraisal of one's assets and liabilities. Some aspects of self-esteem, such as intelligence, appearance and body development, form the natural traits of the person [6]. Coopersmith describes self-esteem as a complex concept composed of identity evaluation, defense mechanisms and different images of certain events. For Coopersmith, self-esteem is an internal image that determines the attitude and behaviors of the person. This internal image is affected by self-evaluation and perception of others [29].

The studies that examine the correlation between self-conception and socio-economic level status emphasize that low socio-economic status leads to low self-conception among the children [5]. It has been argued that hearing loss may trigger paranoid ideation disorder, affective disorders particularly unipolar depression-, psychoses like late-onset schizophrenia, generalized anxiety disorder, acute and posttraumatic stress disorder, personality disorders, self-destructive behavior disorder, substance abuse disorders and numerous other psychiatric disorders [7] [8] [9] [10] [11]. In broadest sense; self-conception may be defined as “one's perceptions about himself". These perceptions are shaped by individuals' experiences and interpretation of the environment. They are affected especially by individuals' significant others' reinforcements and explanations [12] [13].

Studies done previously reported that self-esteem is 
closely associated with a healthy psychology, achievements and coping with the conditions of a stressful life. It is often argued that members of the minority groups have lower level of self-esteem as compared with others owing to belonging to low social ranks. Yet; this argument has systematically been reversed [14].

Those who are deaf from birth or at an early age during prelingual period before learning how to speak succeed in adapting themselves more easily and permanently thanks to such methods as lip-reading or communication with special manual alphabet [15] [16]. The studies conducted with hearing impaired individuals on self-esteem have generally provided inconsistent results [14]. The study of Lane (1992) points out that according previous self-esteem theories, the hearing impaired people have lower level of self-esteem because they are in a less valuable minority group and have probably been affected by negative attitudes of the people with normal hearing [17]. -Unlike the above mentioned study-; in the study of Bat-Cahava (1993-1994); it is proposed that the hearing impaired people do not have lower level of self-esteem and is suggested that there need more studies to examine how hearing loss affects self-esteem [18].

There are many factors that can reinforce and maintain self-confidence of the hearing impaired individuals: (a) type of domestic/familial communication, (b) type of the school from preschool to high school-, (c) age at which hearing loss starts, (d) hearing aids and severity of hearing loss, (e) group description [14]. A high degree of hearing disability that occurs at an early age is considered as if it was a basic obstacle and as a result a lack of communication occurs. The effect of lack of communication is observed in the earliest forms of communication of the hearing impaired children. Early development of mother-child attachment, which is necessary to form positive emotions about self-concept, is frequently hindered by lack of communication from which the hearing impaired children suffer. Most of the widespread epidemiological studies undertaken lately support -especially- the correlation between audio visual perception disorders and psychiatric disorders [7] [11] [19] [20].

Ability to communicate, which is critical to form a better quality of life, will be severely and negatively affected among those with hearing loss [8] [21]. Because as the severity and duration of hearing loss increases, so do lack of stimuli and stress level [8] [22].

Decrease in self-esteem and self-confidence results from weak group identity. It is argued that deaf individuals, who have accepted deafness-identity, will have higher self-esteem [23]. Besides; studies report that the hearing impaired students who have severe auditory impairments and have grown up in more than one culture have generally higher level of self-esteem [14].

Society has to incorporate hearing-impaired individuals in sports and recreation activities because this helps these individuals to develop healthier lifestyles in the course of time [24]

Sports activities help disabled people to develop physically, mentally and socially and enable them to socialize [25]. Therefore, sports must be treated as a means of adapting disabled individuals to society, accelerating this process and contributing to their socialization[26]. Weinberg and Gould found that exercise programs lead to significant increases in self-esteem and that increasing levels of exercise and health are related to increases in self-esteem [40]. It is known that high self-esteem generally enables an individual to be more confident about them self and other people, to establish more healthy and satisfying relationships with people, and increases the harmony with people [40] [27].

In the light of this literature, examining the social harmony problems of hearing impaired sportsmen and studying them in relation to their socio-demographic characteristic is among the common mission of educators and sportsmen, as well as trainer and managers who organize and oversee sporting activities with hearing impaired football players. The purpose of the present study is to determine the hearing impaired football players' levels of self-esteem, which has an importance for hearing impaired individuals, is achieved through participation in sporting activities.

\section{Tools and Method}

\section{Data Collection}

It is known that the hearing impaired individuals have had football league in our country for years. In Turkey; there were 32 first league football clubs and 40 second league football clubs in 2011. The population of the current study was composed of 586 hearing impaired football players and the sample was consisted of 95 hearing impaired football players $(16.21 \%)$. The sample was limited to one football club from seven regions of Turkey. The questions in the questionnaire forms were explained by an official sign language interpreter of Hearing Loss Association and civil interpreters who knew the sign language because hearing impaired athletes had difficulty reading and understanding the questionnaire forms. The inclusion criteria for all hearing impaired football players who filled in the questionnaire forms was to have a hearing loss of at least $55 \mathrm{~dB}$ in both ears [28].

\section{Personal Information Form}

A "Personal Information Form" was designed by the researcher and the mentor in order to gather data relating to some variables that were thought to be affecting self-esteem levels among the hearing impaired football players and healthy football players.

\section{Self-esteem Scale}

In the study; in addition to the Personal Information Form developed to ask questions about socio-demographic characteristics of the participant athletes; Coopersmith Self-esteem Inventory which was developed by Coopersmith (1967) and Turkish adaptation of which was made by Özoğul (1988) was used as a measurement tool in order to measure self-esteem of the athletes [29] [30]. CSEI (Coopersmith Self 
Esteem Inventory) has been designed to measure opinions of individuals about social, academic, domestic/familial and individual lives. Coopersmith Self-esteem Inventory has been modified several times since its first introduction (1967). For the current study; its adult form was employed.

\section{CSEI for Adults}

The inventory, designed to measure self-esteem of the adults, includes 25 items and for each item participants provides dichotomous answers "like me" or "not like me". The inventory measures individuals' view of life, domestic/familial relations, social relations and tolerability. High scores to be obtained from the inventory indicate positive and high self-esteem whereas low scores indicate negative and low self-esteem.

\section{Assessment of the Data}

For the data assessment; SPSS statistical software package, frequencies, percentages, distributions, arithmetic means and standard deviations were used. The interpretations and conclusions were supported with tables.

\section{Findings}

In the study; 95 hearing impaired football players were participated.
Table 1. Distribution of the study group in terms of age, sportive age and educational status

\begin{tabular}{ccc}
\hline Age & $\mathbf{n}$ & $\mathbf{\%}$ \\
\hline 17-20 years & 11 & 11.6 \\
21-24 years & 31 & 32.6 \\
$25-28$ years & 36 & 37.9 \\
$\geq 29$ years & 17 & 17.9 \\
Total & 95 & 100.0 \\
\hline Sportive age & $\mathrm{n}$ & $\%$ \\
\hline 1-3 years & 10 & 10.5 \\
4-6 years & 29 & 30.5 \\
7-9 years & 32 & 33.7 \\
$\geq 10$ years & 24 & 25.3 \\
Total & 95 & 100.0 \\
\hline Educational status & $\mathrm{n}$ & $\%$ \\
\hline Illiterate & 29 & 30.5 \\
Primary school & 12 & 12.6 \\
Secondary school & 19 & 20.0 \\
High school & 35 & 36.9 \\
University & - & - \\
Total & 95 & 100.0 \\
\hline
\end{tabular}

Table 2. T test results of the self-esteem levels of the study-group in terms of impairment status

\begin{tabular}{llllllll}
\hline & Impairment status & $\mathrm{N}$ & $\begin{array}{c}\mathrm{Mean} \\
\mathrm{X}\end{array}$ & $\mathrm{S}$ & $\mathrm{sd}$ & $\mathrm{t}$ & $\mathrm{P}$ \\
\hline \multirow{2}{*}{ Self-esteem } & $\begin{array}{c}\text { The hearing impaired } \\
\text { football players }\end{array}$ & 95 & 65.14 & 12.37 & 402 & 2.625 & $.005^{*}$ \\
\hline${ }^{*} \mathrm{p}<0.05$ & & & & &
\end{tabular}

When the above mentioned table was analyzed it was seen that mean self-esteem scores of the athletes statistically and significantly differed in terms of impairment status $[\mathrm{t}(402)=2.625, \mathrm{p}<0.05]$.

Table 3. n, Mean, Sd results related to self-esteem scores of the study groups in terms of age.

\begin{tabular}{ccccc}
\hline & Age & N & Mean & S \\
\hline & 1) $17-20$ years & 11 & 65.45 & 10.77 \\
Self-esteem (the hearing & 2) $21-24$ years & 31 & 64.90 & 13.29 \\
impaired) & 3) $25-28$ years & 36 & 65.56 & 11.45 \\
& 4) $\geq 29$ years & 17 & 64.47 & 14.41 \\
\hline
\end{tabular}

According to the Table; when the self-esteem scores of the hearing impaired football players were assessed; mean self-esteem score of the those aged 17-20 years was (Mean=64.22), mean self-esteem score of those aged 21-24 years was (Mean $=64.90)$, mean self-esteem score of those aged 25-28 years was (Mean =65.56) and mean self-esteem score of those aged 29 years was $($ Mean $=64.47)$.

Table 4. F test (ANOVA) results of the self-esteem scores of the hearing impaired football players in terms of age variable

\begin{tabular}{ccccccc}
\hline & Source of the & Chi-squar & $\mathrm{Sd}$ & Chi-squ & $\mathrm{F}$ & $\mathrm{P}$ \\
\hline \multirow{2}{*}{ Self-esteem (The } & Intergroup & 16.66 & 3 & 5.55 &, 035 &, 991 \\
hearing impaired) & Intragroup & 14372.56 & 91 & 157.94 & & \\
& Total & 14389.22 & 94 & & & \\
& & & & & \\
\hline
\end{tabular}

$* \mathrm{p}<0.05$

When the data in the Table were examined; it was noted that no statistically significant difference existed in mean scores of 
self-esteem of the hearing impaired football players in terms of age variable $[\mathrm{F}(3,91)=.035, \mathrm{p}>0.05]$. Therefore; it may be argued that self-esteem levels of the hearing impaired football players of different age groups were similar. When arithmetic means of self-esteem were evaluated; it was seen that mean self-esteem scores of all age groups were "moderate" [36].

Table 5. n, Mean, Sd results related to self-esteem scores of the study groups in terms of sportive age.

\begin{tabular}{clllc}
\hline & Sportive age & N & Mean & S \\
\hline & 1) $1-3$ years & 10 & 62.80 & 14.49 \\
Self-esteem & 2) 4-6 years & 29 & 66.07 & 12.45 \\
(the hearing impaired) & 3) $7-9$ years & 32 & 63.50 & 8.67 \\
& 4) $\geq 10$ years & 24 & 67.17 & 15.56 \\
\hline
\end{tabular}

According to the Table; when self-esteem scores of the hearing impaired football players were analyzed in terms of sportive age; it was detected that mean self-esteem score of those doing sports for 1-3 years was $(\mathrm{Mean}=62.80)$, mean self-esteem score of those doing sports for 4-6 years was (Mean =66.07), mean self-esteem score of those doing sports for 7-9 years was (Mean $=63.50)$ and mean self-esteem score of those doing sports for $\geq 10$ years was Mean $(=67.17)$.

Table 6. F test (ANOVA) results of the self-esteem scores of the hearing impaired football players in terms of sportive age variable

\begin{tabular}{lcccccc}
\hline & Source of the & Chi-square & Sd & Chi-squa & F & P \\
\hline Self-esteem & Intergroup & 264.43 & 3 & 88.14 &, 568 &, 638 \\
(the hearing & Intragroup & 14124.80 & 91 & 155.22 & & \\
impaired) & Total & 14389.22 & 94 & & & \\
\hline$*_{\mathrm{p}<0.05}$ & & & & &
\end{tabular}

When the data in the Table were examined; it was noted that no statistically significant difference existed in mean scores of self-esteem of the hearing impaired football players in terms of sportive age variable $[F(3,91)=, 568, p>0.05]$. Therefore; it may be suggested that self-esteem levels of the hearing impaired football players of different sportive age groups were similar.

Table 7. n, Mean, Sd results related to self-esteem scores of the study groups in terms of educational status.

\begin{tabular}{lcccc}
\hline & Educational status & N & Mean & S \\
\hline \multirow{3}{*}{$\begin{array}{c}\text { Self-esteem (the hearing } \\
\text { impaired) }\end{array}$} & 1)Illiterate & 29 & 64.41 & 10.44 \\
& 2) Primary school & 12 & 65.00 & 14.98 \\
& 3) Secondary school & 19 & 64.42 & 7.76 \\
\hline
\end{tabular}

According to the Table; as far as educational status was concerned it was seen that mean self-esteem score of the hearing impaired football players who were illiterate was (Mean $=64.41$ ), mean self-esteem score of those primary school graduates was (Mean $=65.00$ ), mean self-esteem score of those secondary school graduates was (Mean $=64.42$ ) and mean self-esteem score of those high school graduates was $($ Mean $=66.17)$.

Table 8. F test (ANOVA) results of the self-esteem scores of the hearing impaired football players in terms of educational status variable

\begin{tabular}{ccccccc}
\hline & Source of the & Chi-square & $\mathrm{S}$ & Chi-squar & $\mathrm{F}$ & $\mathrm{P}$ \\
\hline Self-esteem & Intergroup & 62.58 & 3 & 20.86 & .133 & .94 \\
(the hearing & Intragroup & 14326.64 & 9 & 157.44 & & \\
impaired) & Total & 14389.22 & 9 & & & \\
& & & & & \\
\hline
\end{tabular}

$* \mathrm{p}<0.05$

When the data in the Table were investigated; it was seen that there was no statistically significant difference in mean scores of self-esteem of the hearing impaired football players in terms of educational status variable $[\mathrm{F}(3,91)=.133, \mathrm{p}>0.05]$. Therefore; it may be suggested that self-esteem levels of the hearing impaired football players who had different educational status were similar. When arithmetic means of self-esteem were evaluated; it was seen that mean self-esteem scores of all education groups were "moderate" [36]. 


\section{Discussion}

In the current study which was conducted to examine the level of self-esteem of the hearing impaired football players; the following results were obtained: it was found out that self-esteem of the hearing impaired football players was at moderate level [16]. According to Lane (1992); the hearing impaired people belong to minority group and have low level of self-esteem [17]. Some studies argue that the hearing impaired people trust themselves less than those people with normal hearing [31] [32] while others suggest that prejudgments do not reduce self-confidence [33] [34]. Severity of hearing loss affects self-esteem positively and it is reported that those with severe hearing loss have higher level of self-confidence. It is often proposed that members of minority group have less self-esteem as compared with others because the hearing impaired individuals are in lower social ranks in the society. However; this judgment has systematically been reversed [14].

Even if deafness that occurs in adulthood/adolescence cannot be compared to the deafness from birth or infant deafness; it may cause individuals to lose self-esteem and self-confidence and thus to be more tender and sensitive to the social environment as compared with the pre-deafness period and even to develop paranoid psychotic disorders. In fact; it is reported that those who are subjected to hearing loss in old age suffer from paranoid psychosis more than the normal population [36] [38].

Those who are deaf from birth or at an early age during prelingual period before learning how to speak succeed in adapting themselves more easily and permanently by learning such methods as lip-reading or communication with special manual alphabet [15].

When the data in the current study were analyzed; it was found out that no statistically significant difference existed in mean scores of self-esteem of the hearing impaired football players in terms of age variable $[\mathrm{F}(3,91)=.035, \mathrm{p}>0.05]$. When arithmetic means of self-esteem were evaluated; it was seen that mean self-esteem scores of all age groups were "moderate" (30-70). Age and self-concept affect people's aging process directly or indirectly [16] [37].

It was seen that there was no statistically significant difference among the mean self-esteem score of hearing impaired football players in terms of sportive age. There is a positive correlation between doing sports and self-esteem level. Therefore; participation in sportive activities increases self-esteem and in turn having high self-esteem increases success in sports [39][40]. There is a positive correlation between doing sports and life satisfaction [46]. Thus; participation in sportive activities increases self-esteem and in turn having high self-esteem increases success in sportive activities [40]. Exercises programs seem to lead significant increases in self-esteem. The increased levels of exercises and health are in parallel to the increased self-esteem [40]. According to Açak and Karademir (2011) self esteem of hearing impaired students participating in sports activities is higher than those who don't participate and it is possible to say that sports activities have a positive effect on self esteem of the impaired students who haven't got much chance to participate in activities. [47]

It was found out that there was no statistically significant difference among the mean self-esteem score of hearing impaired football players in terms of educational status $(p>.05)$. In light of this finding; it may be argued that self-esteem levels of different education groups were at similar level.

Some studies propose that academic success affects self-esteem positively while others argue just the opposite. According to Liu, Kaplan \& Risser (1992); some studies maintain that there is a positive correlation between self-esteem and academic success while the study of Hewitt (1998) indicates that this correlation between self-esteem and academic success is quite weak and has been superficially interpreted [41] [42]. Schools should prepare hearing impaired children for social opportunities which include participation in events which involve the hearing impaired society that they will encounter as individuals. The lack of interest in out-of-lesson sports activities, which support the general education of a hearing impaired individual, is especially a problem in public schools [48]

According to some studies done with ethnic minority groups; such factors as family support and school experiences affect self-esteem of minority groups to a large scale [43] and these studies indicate that minority students of strong familial bonds have higher level of self-esteem. Besides; it is more likely that students who have more positive school experiences and who undergo less discrimination develop positive self-esteem. Bat-Chava (1993) has proved that these factors are also important and true for the hearing impaired individuals [31]. In the study of Y1lmaz and Arikan (2008) done with 100 1st, 2nd and 3rd grade adolescent students who studied at a multi-program high school; it was detected that self-esteem of the hearing impaired adolescents were at moderate level [44].

Even if deafness that occurs in adulthood/adolescence cannot be compared to the deafness from birth or infant deafness; it may cause individuals to lose self-esteem and self-confidence and thus to be more tender and sensitive to the social environment as compared with the pre-deafness period and even to develop paranoid psychotic disorders. In fact; it is reported that those who are subjected to hearing loss in old age suffer from paranoid psychosis more than the normal population [35] [36]. Most of the widespread epidemiological studies undertaken lately support -especially- the correlation between audio visual perception disorders and psychiatric disorders [7] [19] [45].

Karademir (2012) states that hearing impaired individuals have a special culture and language. Increasing the number of studies concerning hearing impaired individuals may be an important step for understanding and solving the problems in communicating with these people who are members of society. Even problems concerning the participation in sports activities can be detected and measures can be taken in order to solve them as well as 
taking part in sports activities increases self-esteem [49].

It was seen that there was no statistically significant difference in mean self-esteem scores of the hearing impaired football players in terms of living-place variable ( $>$.05). With this finding in hand; it may be suggested that self-esteem levels of the hearing impaired football players who lived in different living-places were at similar levels. It is an important issue that no significant differences were found among the variables; which should be examined. It is interesting that studies done with hearing impaired individuals are contradictory with each other and therefore it follows that it is necessary that new studies should be undertaken.

\section{REFERENCES}

[1] Adams SG, Gullotta T. (1989). Adolescent life experiences. New York: Brooks Cole Publishing Company,

[2] André C, \&Lelord F. (2002). Kendine Saygı. Çev. Yerguz, İ. (2. Baskı):: İletişim Yayınları. İstanbul.

[3] Cuhadaroğlu F. (1996). Adolesansta Psikolojik GelisimOzellikleri, Katk1 Pediatri Dergisi, 17, 5, 273-288.

[4] Gectan E. (1984). Psikanaliz ve Sonras1, Maya Matbaacılık. Ankara.

[5] Güleç HC.(1999). Özel Sınıflara ve Kaynaştırılmış Sınıflara Devam Eden İlkokul Düzeyindeki Eğitilebilir Zihinsel Engelli Çocuklarla Engelli Olmayan Çocukların Benlik Kavramlarının Karşılaştııılması. Yayımlanmamış Doktora Tezi. Ankara

[6] Chrzanowski G. (1980). The genesis and nature of self-esteem. Am J Psychother, 35:38-46

[7] Black PA, Glicman NS.(2006) Demographics, psychiatric diagnosis, and other characteristics of 0northamericandeafand hard-of-hearing in patients. J Deaf Studies Education; 11:303-21.

[8] Eriksson MM, Carlsson SG.(1991). Psychological and somatic distress in the relation to perceived hearing disability, hearing handicap and hearing measurements. J Psychosom Research. 35:729-40.

[9] Leposavic L, Leposavic I, Jasovic G. M.(2006). Psychosocial aspects of acquired hearing impairment in the patients with otosclerosis. Psychiatr Danub; 18:30-8.

[10] Malmo RB, Malmo HP, Ditto B.(2003). On reversible deafness, generalized anxiety disorder, and the motoric brain: a psychophysiological perspective. Int $\mathrm{J}$ Psychopysiol; 48:97-113.

[11] Singerman B, Riender E, Folstein M.(1980). Emotional disturbance in hearing clinic patients. B.J. Psychiatry; 137:58-62.

[12] Bıyıklı L.(1989) Bedensel Özürlü Çocukların Benlik Kavramı (Aile Kabul Düzeyi Acısından). Ankara Üniversitesi Basımevi. Ankara.
[13] Erkan G.(1990). Ortopedik Özürlü Çocukların Kendini Kabul Düzeyi Üzerine Bir Araştırma. Sakatları Koruma Milli Koordinasyon Kurulu. İstanbul.

[14] Jambor E, Elliott M.(2005). Self-esteem and Coping Strategies among Deaf Students. Journal of Deaf Studies and Deaf Education vol. 10 no. 1 p:63-81.

[15] Stefanis N, Thewissen V, Bakoula C.(2006). Hearing impairment and psychosis: a replication in a cohort of young adults. Schizophr Res; 85:266-72.

[16] Topuz R, Sanioğlu A, Çağlayan HS. (2010). Amatör Futbol Oyuncularının Saldırganlık Düzeylerinin İncelenmesi Selçuk Üniversitesi Beden Eğitimi ve Spor Bilim Dergisi, 12 (1), 4249.

[17] Lane H. (1992). The mask of benevolence. Vintage Books. New York

[18] Bat-Chava Y. (1994). Group identification and self-esteem of deaf adults. Personality and Social Psychology Bulletin, 20, 494-502.

[19] Atkinson J.(2006). The perceptual characteristics of voice hallucinations in deaf people: insight into the nature of subvocalt thought and sensory feedback loops. Schizophrenia Bul; 32:701-8.

[20] Kenna M L, Hallam RS, Hinchcliffe R.(1991). The prevalence of psychological disturbance in neuro-otology out patients. Clin Otolaryngology; 16:452-6.

[21] Way N, \&Robinson MG. (2003). A longitudinal study of the effects of family, friends, and school experiences on the psychological adjustment of ethnic minority, low-SES adolescents. Journal of Adolescent Research, 18, 324-346.

[22] Fellinger J, Holzinger D, Dobner U.(2005). Mental distress and quality of life in a deaf population. Soc Psychiatry Psychiatr Epidemiol; 40:737-42.

[23] Andrews JF, Leigh IW, \&Weiner MT,(2004). Deaf people: Evolving perspectives from psychology, education, and sociology. Boston: Allyn\& Bacon.

[24] Stewart DA, Ellis MK. (2005). Sports and the deaf child. Am Ann Deaf, 150,1 Academic Research Library pp.59-65.

[25] Eichsteadt CB, Lavay BW. (1995). Physical activity for individuals with mental retardation. Compaign, Illinois, pp.47

[26] Dunn JM, Fait H. (1997). Special physical education: Adapted, individualized, developmental. Seventh Edition, Iowa Dubuque Brown \& Benchmark, pp. 22.].

[27] Asci FH. (1999). Benlik kavrami ve spor. Spor psikolojisi kursu. P Bayar (Der), Ankara, Bagirgan Publishing,

[28] Greydanus DE, Patel DR, Baker RJ. (2009). Pediatric Practice Sports Medicine. New York, USA: McGraw-Hill Professional Publishing, p. 440-441.

[29] Coopersmith S.(1967). The Antecedents of Self Esteem, Coleand Freeman, Co., San Francisco.

[30] Özoğul N.(1988). Annenin Çalısmasının ve Bazı Bireysel Niteliklerin Çocugun Özsaygısına Etkisi. Hacettepe Üniversitesi Sosyal Bilimler Enstitüsü Yayınlanmamıs Yüksek Lisans Tezi, Ankara. 
[31] Bat-Chava, Y. (1993). Antecedents of self-esteem in deaf people: A meta-analytic review. Rehabilitation Psychology, $38,221-234$.

[32] Schlesinger HS. (2000). A developmental model applied to problems of deafness. Journal of Deaf Studies and Deaf Education, 5, 349-361.

[33] Emerton RG. (1996). Marginality, biculturalism, and social identity of deaf people. In I. Parasnis (Ed.), Cultural and language diversity and the deaf experience. pp. 136-145.

[34] Crowe TV. (2003). Self-esteem scores among deaf college students: An examination of gender and parents' hearing status and signing ability. Journal of Deaf Studies and Deaf Education, 8, 199-206.

[35] Bentall RP, Taylor JL. (2006). Psychological processes and paranoia: implications for forensic behavioural science. Behav Sci Law; 24:277-94.

[36] Cooper AF.(1976). Deafness and psychiatric illness. BJ Psychiatry, 129:216-26

[37] Markus HP, Herzog AR.(1992). The role of the self-concept in aging. In. K. W. Shaie and M.P. Lawton (Eds.) Annual Review of Gerontology and Geriatrics, New York: Springer,11, pp.111.

[38] Erman KA, Şahan A, Can S.(2004) Sporcu Bayan ve Erkeklerin Self-esteem Düzeylerinin Karşılaştırılması. 8. Uluslararası Spor Bilimleri Kongresi. Antalya.

[39] Gün E. (2006). Spor Yapanlarda ve Spor Yapmayan Ergenlerde Self-esteem. Yayımlanmamış Yüksek Lisans Tezi. Adana.

[40] Weinberg RS, Gould D. (1995). Foundations of Sport and Exercise Psychology. Human Kinetics. Champaign/ U.S.

[41] Hewitt JP. (1998). The myth of self-esteem. St. Martin's Press.
New York.

[42] Liu X, Kaplan HB, \&Riser W. (1992). Decomposing the reciprocal relationships between academic achievement and general self-esteem. Youth and Society, 24, 123-148.

[43] Verkuyten M. (2003). Ethnic in-group bias among minority and majority early adolescents: The perception of negative peer behavior. British Journal of Developmental Psychology, $21,543-564$.

[44] Yilmaz F,ve Arikan D. (2008). Hearing impaired Adölesanların Benlik Kavramı Ve Depresyon Belirti Düzeyleri Arasındaki İlişki. Atatürk Ünv. Hemşirelik Yüksekokulu Dergisi. 11: 4.

[45] Cooper AF, Curry AR, Kay DW. (1974). Hearing loss in paranoid and affective psychoses of the elderly. Lancet; 304:851-4.

[46] Açak, M. (2012). Self-esteem levels among hearing impaired athletes participating in the European Futsal championship, EEST Part B Social and Educational Studies, 4(3): 1523-1534).

[47] Açak, M. and Karademir, T. (2011). The Analysis of Hearing Impaired Students' Self Esteem According to Some Variables, Inonu University Journal of the Faculty of Education, Vol.12 (2), pp. 165-179.

[48] Stewart DA, Stinson M. (1992). The role of sport and extracurricular activities in the shaping of socialization patterns of deaf and hard of hearing students. Ġn T. Kluwin, D. Moores, \& M. Gaustad (Eds.), Ibuiard effective public school programs for deaf students

[49] Karademir, T. (2012). An examination of the relationship between sports activity and the life satisfaction levels of hearing impaired studies, EEST Part B Social and Educational Studies, 4(3): 1857-1864. 